\title{
Manetti's Socrates and the Socrateses of Antiquity
}

\section{Citation}

Hankins, James. 2008. Manetti's Socrates and the Socrateses of antiquity. In Dignitas et excellentia hominis: Atti del convegno internazionale di studi su Giannozzo Manetti, Ed. Stefano U. Baldassarri, 203-219. Florence: Le Lettere.

\section{Permanent link}

http://nrs.harvard.edu/urn-3:HUL.InstRepos:2961810

\section{Terms of Use}

This article was downloaded from Harvard University's DASH repository, and is made available under the terms and conditions applicable to Other Posted Material, as set forth at http:// nrs.harvard.edu/urn-3:HUL.InstRepos:dash.current.terms-of-use\#LAA

\section{Share Your Story}

The Harvard community has made this article openly available.

Please share how this access benefits you. Submit a story.

\section{Accessibility}




\section{Manetti's Socrates and \\ the Socrateses of Antiquity}

Towards the middle of his Life of Socrates (c.1440), the first biography of the great philosopher written since antiquity, Giannozzo Manetti roundly states that the opinions attributed to Socrates in the books of Plato were genuine, and that furthermore they were shared by Plato too:

Nullum igitur doctrinae [Socratis] apud nos monumentum extat, nisi si quis forte Platonis libros Socratis, magistri sui, monumenta appellare vellet. In quibus fere omnibus, cum Socrates loquens exprimatur, eas Socratis sententias fuisse vere simul atque eleganter dici potest quae in Platonis dialogis illius verbis efferuntur; et versa vice eas Platonis opiniones extitisse dicemus, quae ex ore Socratis pronuntiantur. ${ }^{1}$

The remark is one that a modern classical scholar could not but regard as staggeringly naïve, given the shelves full of books that have been written over the last two centuries attempting to recover the historical Socrates and, in particular, to distinguish his teaching from that of Plato. Recent students of Socrates, indeed, tend to despair of finding the 'real' Socrates behind the surviving sources and prefer to speak instead of the images of Socrates projected by particular writers, schools and traditions. Hence we have the Aristophanic Socrates, a natural philosopher, sophist and free thinker; the pedestrian teacher of conventional morality portrayed by Xenophon; the logic-chopping soul-doctor of Plato; the skeptical Socrates of the Hellenistic Academy; Cicero's Socrates, the fountainhead of all Greek philosophical schools; the morally ambivalent Socrates of the early Christians; and the sublime metaphysical Socrates of the Neoplatonists. ${ }^{2}$ But despite his remark quoted above, the image of Socrates presented to us by Manetti, deeply colored though it is by the Platonic Socrates, nevertheless presents an image of him that is in the end quite distinct from Plato's, both in life and in doctrine. Manetti's biography at first sight appears to be a congeries of quotation and anecdote of varying ideological provenance; indeed there is very little in the biography that is not quoted or paraphrased from some identifiable source. The argument of this essay is that the seemingly random collection of material is in fact carefully curated to achieve a particular purpose; it achieves its effect pointillistically by the arrangement and juxtaposition of facts, quotations and anecdotes. Manetti selected material from among the numerous

${ }^{1}$ Giannozzo MANETTI, Biographical Writings, a cura di S. Baldassarii, Cambridge (Massachusetts) 2003, p. 199 (\$30). Subsequent references to Manetti's Vita Socratis will be to the paragraph numbers of this edition. All quotations in English below are from Baldassarri's translation.

${ }^{2}$ Remembering Socrates: Philosophical Essays, a cura di L. Judson and V. Karasmanis, Oxford 2006; A Companion to Socrates, a cura di S. Ahbel-Rappe and R. Kamtekar, Oxford 2006; Socrates from Antiquity to the Enlightenment, a cura di M. Trapp, Aldershot and Burlington 2007. G. Vlastos, Socrates: Ironist and Moral Philosopher, Ithaca (New York) 1991, argues that we have several Socrateses in the dialogues of Plato. 
'Socrateses' preserved in ancient sources so as to produce a new image of Socrates that is intended to make him into an authority for and an exemplum of the humanist cultural project. Manetti's Socrates represents the embodiment of what early humanism thought a philosopher should be and carries on the humanist critique of contemporary school philosophy pioneered by Petrarch and continued by Salutati and Manetti's teacher, Leonardo Bruni. ${ }^{3}$

Manetti was fortunate in having access to a wider range of sources for the life and teaching of Socrates than any previous scholar in Latin Christendom. Analysis of the Vita Socratis discloses that he made use of testimonia in Aristotle, Cicero, Valerius Maximus, Seneca, Aulus Gellius, Apuleius, Augustine and Jerome. All of these works, to be sure, might have been used by a medieval scholar with an exceptional library at his disposal. ${ }^{4}$

But Manetti also benefitted from a number of key sources that only became known in the Latin West as a result of the Hellenic revival sparked by Manuel Chrysoloras in the decades after 1400. Thus Manetti gained access to Plato's Phaedo, Crito, Apology, Gorgias, and Alcibiades' speech from the Symposium, ${ }^{5}$ translated by his teacher, Leonardo Bruni; Xenophon's Apology of Socrates, also translated by Bruni; ${ }^{6}$ and - most important of all - the lives of Socrates, his teachers and his disciples that make up book 2 of Diogenes Laertius' Lives of the Philosophers, translated into Latin in 1431 by the Camaldolese monk, Ambrogio Traversari. Manetti remained ignorant, sadly, of other key Greek sources such as the plays of Aristophanes, the rest of the Platonic dialogues and the numerous testimonia in the Greek Church Fathers, Lucian, Dio Chrysostom, Plutarch's Moralia, Athenaeus, Maximus of Tyre and, most regrettably, three of the four 'Socratic' works of Xenophon. Though Bessarion translated the Memorabilia in 1442, two years after the initial dedication of Manetti's Socrates to Nuño de Guzmán but a decade before the work was rededicated to King Alfonso of Aragon and Naples, ${ }^{7}$ it seems

\footnotetext{
${ }^{3}$ On the humanist view of what philosophy should be, see J. HANKIns, Humanism, Scholasticism and Renaissance Philosophy, in The Cambridge Companion to Renaissance Philosophy, a cura di J. Hankins, Cambridge 2007, pp. 30-48. Fuller details on the cultural context of Manetti's Socrates may be found in J. HANKINS, Socrates in the Italian Renaissance, in Socrates from Antiquity, pp. 179-208.

${ }^{4}$ The twelfth-century translations of the Meno and Phaedo by Henricus Aristippus were literal to the point of unintelligibility and in any case enjoyed extremely limited circulation (though Petrarch and Salutati had copies of the Phaedo version). The only work of Plato widely studied in the Middle Ages was the first third of the Timaeus, which had been translated into Latin in the fourth century by Calcidius. See J. HANKINS, Humanism and Platonism in the Italian Renaissance, I-II, Roma 2003-2004, pp. 93-142. ${ }^{5}$ A Latin text and English translation of the latter is in HANKINS, Socrates, pp. 196-203. There are modern editions of Bruni's two versions of the Crito in Bruni 1983.

${ }^{6}$ The least ambiguous evidence that Manetti read Bruni's translation of Xenophon's Apology comes at $\$ 20$, where Manetti says 'Atque, ita moriens, multiplices humanae vitae molestias evitaret', which echoes Xenophon's Apologia Socratis 6 and 32, and is not paralleled by any passage in Plato or Diogenes Laertius. In the account of Socrates' death Manetti generally follows Plato's rather than Xenophon's Apology.

${ }^{7}$ M. PADE, The Reception of Plutarch's Lives in fifteenth-century Italy, I-II, Kobenhavn 2007, I, p. 337 (n. 993), makes the interesting point that Alfonso of Aragon was pleased
} 
that Manetti did not know the version, or if he did, he chose not to add new material from it to his biography after its initial publication. And there is no evidence in the Vita that he knew either Xenophon's Oeconomicus or his Symposium. ${ }^{8}$ Nevertheless, Manetti's industry in gathering together relevant texts remains impressive.

It cannot be said, however, that the resulting composition was a masterpiece of the biographical genre, or that Manetti fully succeeded in digesting his sources and producing a coherent picture of the great Athenian philosopher. As stated above, at first sight the biography appears to be an ill-assorted patchwork of quotations and paraphrases from diverse sources, arranged roughly by topics but with frequent digressions, repetitions and awkward transitions. It cannot be compared in clarity of presentation or critical acumen with Bruni's biographies of Cicero, Aristotle, Dante and Petrarch. But there are some resemblances in method. Bruni took Plutarch's life of Cicero as the core of his own biography, but then integrated new material, mostly from Cicero's own works, and produced a fresh assessment of the Roman orator's role in Roman political life and his literary merit. ${ }^{9}$ Manetti likewise uses material from Diogenes Laertius as the core of his own biography, often quoting from or paraphrasing Traversari's translation, but he reorders Diogenes' material and integrates testimonia from his other sources, while cutting out many of the witty sayings and maxims attributed to Socrates as well as much titillating gossip and merely antiquarian detail. He vastly expands Diogenes' brief treatments of Socrates' pedagogy, his daimonion and the account of the trial and death of Socrates, where he draws directly on Apuleius' De deo Socratis and on Bruni's translations. Moreover, in the case of some anecdotes he substitutes a version from another source in place of the version found in Diogenes. For example, in telling the story of how Socrates' student Aeschines offered himself to Socrates, Manetti prefers the version in Seneca's De beneficiis to the one in Diogenes, surely because it better highlights Socrates' devotion to the moral improvement of his disciples.

Diogenes Laertius (Venice, 1475), 2.34, tr. Traversari

Cum sibi dixisset Aeschines, Pauper sum, et aliud habeo nihil: me ipsum autem tibi do. An vero tu, inquit, non animadvertis quam mihi maxime tradis?

to be associated with Socrates (and Seneca), and that Panormita's anecdotal biography of the king, De dictis et factis Alfonsi regis, mirrored the fifteenth-century title of Xenophon's Memorabilia, De dictis et factis Socratis. On this work see also Dennis E. Rhodes, Il cardinal Bessarione e Senofonte, in Miscellanea Marciana di studi bessarionei (a coronamento del V centenario della donazione nicena), a cura di Rino Avesani et al. (Medioevo e Umanesimo, 24), Padova 1976, 353-356, and Michele Bandini, I «Memorabili» di Senofonte fra il Bessarione, Isidoro di Kiev e Pier Vettori, «Bollettino dei classici», 12 (1991), 83-92.

${ }^{8}$ See J. HANKIns-A. PALMER, The Recovery of Ancient Philosophy in the Renaissance: A Brief Guide, Firenze 2008, pp. 6-7, for the Renaissance recovery of the sources for Socrates' life and teaching.

${ }^{9}$ G. IANZITI, Leonardo Bruni and Biography: the Vita Aristotelis, «Renaissance Quarterly» 55.3 (2002), pp. 805-32. 
Socrati quum multa multi pro suis quisque facultatibus offerrent, Aeschines pauper auditor: 'Nihil, inquit, dignum te, quod dare tibi possim, inuenio, et hoc uno modo pauperem me esse sentio. Itaque dono tibi quod unum habeo: me ipsum. Hoc munus rogo qualecumque est, boni consulas, cogitesque alios, quum multum tibi darent, plus sibi reliquisse'. Cui Socrates : 'Quidni tu', inquit, 'mihi magnum munus dederis, nisi forte paruo te aestimas? Habebo itaque curae, ut te meliorem tibi reddam quam accepi'.

\section{Manetti, Vita Socratis, cap. 24}

Unde Aeschines, unus ex discipulis, cum ita pauper esset ut ob paupertatem neque pecuniam neque munera dare posset, 'Nihil,' inquit, 'te dignum invenio quod tibi donare valeam, in quo uno me pauperem et inopem esse recognosco. Itaque me ipsum, quo nihil carius habeo, tibi do.' Cui Socrates humanissime simul atque liberalissime respondisse fertur: 'Magnum mihi munus dedisti. Conabor igitur ut meliorem te tibi reddam quam acceperim' (24).

In general, Manetti's account differs from Diogenes in being far more high-minded in tone and panegyrical in purpose. His life of Socrates is in effect a laudatio Socratis: what gives it coherence above all is his presentation of Socrates as an exemplar of the moral and intellectual virtues. The emphasis on Socrates' virtues provides Manetti with a principle of selection, while his arrangement of materials follows a broadly chronological sequence, as can be seen from the following analysis of topics:

\section{Outline of Manetti's Vita Socratis}

1-13 Preface to King Alfonso of Aragon

13-14 Socrates' place of birth, parentage, dates

14-15 His natural gifts, education and military service

16-17 His turn to ethics and his career as a moral philosopher

18-20 His studies of dialectic, music, natural philosophy

20-21 The oracle of Apollo's judgement about Socrates

22-26 His teaching and its influence on Greek philosophy

27-28 His intellectual gifts

29-30 His profession of ignorance and his irony

30 Records of Socrates' life and thought

31 Socrates as a living oracle.

32-36 Physical appearance, domestic habits and marriages

37-38 Public life; his patience

39-42 His other virtues: justice, temperance, gentleness

43-44 His physical toughness and plain living

45-50 Socrates' tutelary daimon.

51-55 The trial and condemnation of Socrates; his courage

56-61 Imprisonment and death 
63 Other persons of the same name.

Manetti's praise of Socrates' virtues pursues, implicitly, two broad lines of argument. The first is that Socrates perfectly exemplifies the way of life advocated by civic humanists like Salutati, Bruni, Poggio, and Manetti himself. ${ }^{10}$ Socrates was a public-spirited citizen who fought for Athens as a exceptionally brave soldier and who held offices and magistracies rarely but with distinction. He could not be corrupted by money or honors. He dressed simply and lived frugally. He had so much respect for the laws of his city that he refused an easy escape from prison, even though he had been unjustly condemned to death, because to break the laws would be factum turpe quoddam et scelestum facinum. He married and raised a family. He devoted his life to teaching good moral behavior to young Athenians, a service he performed gratis. His studies comprehended a wide range of subjects, including letters, logic and natural philosophy. Nor was he ignorant of the softer arts, for he wrote poetry, played the lyre, and engaged in bodily exercise, including dancing. (Manetti uses Socrates' example as an excuse to argue at length for the seemliness and utility of each of these arts.) But though he had the skills of a courtier he rarely travelled, refused offers to join the courts of kings and potentates, and preferred life as a citizen of a powerful, free and cultured city (\$23).

He stood outside and above class and party politics and acted as the moral censor of Athens. He faced down the recklessness of the mob with great courage, but was also ready to speak truth to powerful men. In $\S 38$, Manetti juxtaposes two anecdotes from Diogenes Laertius and Valerius Maximus to make this point. In the first, Socrates resists pressure from 'thirty extremely powerful men' (i.e. the oligarchy of the Thirty, which ruled Athens in 404/3 BC) and voted to acquit Leon of Salamis, whom they were trying to destroy. Although Manetti is paraphrasing Diogenes Laertius (2.24) at this point, he chooses to leave out Diogenes' statement that Socrates was demokratikos. ${ }^{11}$ The second anecdote, from Valerius Maximus (3.8.ext.3), tells how Socrates used his office as President of the Assembly to resist a mob that was raging to commit judicial murder against ten generals who had in truth deserved well of the state. So Socrates in Manetti's telling was a partisan of neither the oligarchs nor the demos. He was a kind of moral censor who was allowed by right to challenge the mores of his fellow citizens. Manetti is careful to say, quoting Cicero, that Socrates had the standing to correct his fellow citizens because of his own superhuman virtues, but most people would not enjoy the same right to speak against the mores and established customs of their city ( 23$)$.

Florentine civic humanists, like all humanists, placed great emphasis on the need to acquire eloquence, but this aspect of Socrates presents Manetti with a challenge in assimilating Socrates to the program of humanism. He insists $(\S 18)$ that Socrates was acer et promptus ad dicendum and skilled in the art of discussion (ars disserendi, quam

${ }^{10}$ On civic humanism see Renaissance Civic Humanism: Reappraisals and Reflections, a cura di J. Hankins, Cambridge 2000.

${ }^{11}$ Traversari translates: 'Erat autem constantis animi invictaeque sententiae et imprimis popularis dominationis studiosus.' 
Graeci 'dialecticen' appellant), but he stops short of claiming that the Athenian was a polished or elegant orator. He was less a fine speaker than an upright teacher $(\S 30)$. In his life of Aristotle (1429) Bruni had had no difficulty in arguing for the eloquence of Aristotle, and Guarino had made similar claims about Plato in his 1430 biography, ${ }^{12}$ but Manetti's sources were less cooperative. Indeed, he had to contend with Cicero's positive statement that Socrates had been condemned nullam aliam ob culpam nisi propter dicendi inscientiam (\$54, quoting Cicero’s De oratore 1.54.231-33).

Manetti responded by discussing at length ( $\S 53-56)$ the story, preserved in several sources, of how the professional orator Lysias had offered Socrates an 'elegant and effective' speech to give at his trial but had been refused. The story gives Manetti a chance to explain that Socrates refused to use Lysias' speech because it projected a dishonorable persona, that of a man who was humble and pleading before his judges, rather than that of an innocent and courageous man. Socrates failed to hire an advocate or employ himself the arts of rhetoric not because of his imperitia sermonis but because of his contemptus mortis (\$59). The correct rhetorical strategy to win his case would have required him to act dishonorably and deny the value of his previous life. In other words, Socrates failure to vindicate himself before his judges was not a rhetorical failure but a moral victory. Manetti, himself a famous orator, thus sees Socrates' trial as a special rhetorical situation where losing the case is in reality to win it. It does not entitle us to say that Socrates was ignorant of rhetoric, or (as Plato argued in the Gorgias) that there was a deep contradiction between the practice of rhetoric and the practice of the philosophical life. To elaborate on latter contrast would have threatened the whole humanistic project, but Manetti (like Cicero and most humanists) prefers not to regard the traditional rivalry of philosophy and rhetoric as a deep and irreconcilable rift between two forms of personal formation. Manetti's wider message is that the true philosopher is a man of deep literary culture, devoted to his city-state, who practices and teaches virtue, embodies wisdom in his life, and uses eloquence as a instrument of virtue and wisdom.

Manetti's second broad line of argument in his biography aims to prove that Socrates' conduct and beliefs, and by implication true philosophy, were compatible with the teachings of Christianity. Here, as he must have known, his judgment was in direct conflict with that of the ancient Church Fathers. The Fathers took a distinctly negative view of Socrates - in fact they remain today the primary conduit for our knowledge of the ancient pagan anti-Socratic tradition. To be sure, Socrates is sometimes used as a positive example when he is being exploited instrumentally for apologetic purposes: how could the pagans persecute Christians, the early Fathers asked, when their own hero Socrates had also been a monotheist who had been unjustly condemned for rejecting the traditional gods? But more typically Socrates was treated as a corrupt representative of the Greek philosophical tradition, with which ancient Christians felt themselves to be in rivalry. Denigrating the father of philosophy was thus a strategy to establish the moral superiority

${ }^{12}$ The Humanism of Leonardo Bruni: Selected Texts, trad. ingl. di G. Griffiths, J. Hankins e D. Thompson, Binghamton (New York) 1987, pp. 262-74 (for Bruni's Life of Aristotle); HANKINS, Humanism and Platonism, II, pp. 67-72 (for Guarino's Life of Plato). 
of the Christian religion. So Socrates was mocked as a pagan wise man who could not control his own lust and anger (Cyril of Alexandria and Theodoret), as a promiscuous homosexual and pedophile (Clement of Rome, Tertullian, Cyril), as a self-confessed ignoramus (Ps.-Justin, Lactantius and Jerome), as a charlatan and a sophist (the emperor Constantine I), and as a demon-worshipper (Tertullian, Minucius Felix, Origen and Cyprian). ${ }^{13}$

For obvious reasons Manetti chose not to engage in any explicit way the Church Fathers' abuse and mockery of Socrates, but he provides emollients to soothe the conscience of any reader worried about the suitability of Socrates as a moral model for Christians. Following Bruni (and making use of Bruni's bowdlerized version of the speech of Alcibiades in the Symposium ${ }^{14}$ ), Manetti rejects out of hand any suggestion that Socrates might have yielded to physical lust for young men like Alcibiades $(\$ \S 24,47)$; he tells Cicero's well-known anecdote about Socrates and the physiognomist Zopyrus $(\$ 44)$ to forestall any insinuations that Socrates' interest in young men might have had any other motive than concern for their moral welfare. Diogenes Laertius' gossipy suggestion (2.19) that Socrates had been the paidika or boy lover of his teacher Archelaus is of course suppressed, as is his remark, passed with a note of surprise, that 'there were those who said [Socrates] rejected Alcibiades' extraordinary good looks' (2.31). ${ }^{15}$ Whereas Jerome had used as arguments against marriage the comical stories of Socrates' humiliation at the hands of his wives, ${ }^{16}$ Manetti recycles Jerome's anecdotes to illustrate Socrates' supreme virtue of patience ( $\S 33-36)$. In general, ancient praise of Socrates for his enkrateia or self-control in Manetti's hands becomes praise of him for the Christian virtue of patience, just as Manetti turns Socrates' professions of ignorance into the Christian virtue of humility ( $\$ 29$ : in hac tam humili nihil sciendi professione).

Manetti had a greater hermeneutical challenge in dealing with the story of Socrates' daimonion, the attendant spirit who warned Socrates at key moments of his life against taking some course of action. The difficulty was not simply that there are numerous passages in the Church Fathers jeering at Socrates' 'demon' and insinuating that the fountainhead of Greek philosophy was possessed by an evil demon. The issue was even more acute, in that St. Augustine, the chief doctor of the Western Church, had spent much of books 8-10 of the City of God arguing against the demonology of the Platonists, using Apuleius' De deo Socratis as his point of departure - the very text Manetti uses as his main source in the long discussion ( $\S \S 45-50)$ of Socrates's attendant spirit. Augustine argues that demons are not intermediate essences in the Chain of Being between the gods and men, as the Platonists had argued. Only Christ can be a true intermediary between God and man. Following the Biblical view of demons, Augustine denied that there were good demons. For him, as for the Church Fathers generally, all

${ }^{13}$ See M. Frede, The Early Christian Reception of Socrates, in Remembering Socrates, 188-202; M. EDWARDS, Socrates and the Early Church, in Socrates from Antiquity, pp. 127-141.

${ }^{14}$ See J. Hankins, Plato in the Italian Renaissance, I-II, Leiden 1990, I, pp. 80-81; HANKINS, Socrates, pp. 187, 190.

${ }^{15}$ Traversari simply transliterates the Greek word paidika, and translates the sentence about Alcibiades as: 'Sunt qui dicant illum Alcibiadis eximiam formam aspernatum.' ${ }^{16}$ Adv. Jovin. 1.48 (= PL 23: 278). 
demons were by definition evil (9.19), inferior in metaphysical dignity to mankind, and the pagan gods held the same cosmic rank as the demons of the Bible. The position held by the gods in the Chain of Being, according to the Platonists, for Augustine was reserved for the angels. In his discussion of Apuleius' book, Augustine leaves open the possibility that Socrates' daimonion might have belonged to a genus of numina different from that of the demons:

Aut ergo fallitur Apuleius et non ex isto genere numinum habuit amicum Socrates ... aut non est Socrati amicitia daemonis gratulanda. De qua usque adeo et ipse Apuleius erubuit, ut De deo Socratis praenotaret librum, quem secundum suam disputationem, qua deos a daemonibus tam diligenter copioseque discernit, non appellare de deo, sed de daemone Socratis debuit. Maluit autem hoc in ipsa disputatione quam in titulo libri ponere (8.14).

Manetti seizes on this possibility and asserts positively, as Augustine had not, that Socrates' daimonion was a good angel. ${ }^{17}$ According to a long-established theological tradition in the Church, all men had a good angel to act as their guardian, guide and educator, and a bad angel to test their faith. ${ }^{18}$ Manetti asserts that this was the case with Socrates, with the difference that Socrates, 'owing to his unique and conspicuous moral excellence,' always obeyed his good angel, never his bad (\$46).

This was an extraordinary assertion of the attainability of human moral excellence in the absence of Christian grace, dubious in its theological orthodoxy, and prima facie one might conjecture that Manetti believed Socrates to have access, via his daimonion, to non-human sources of wisdom denied to other men qua men. There are a few statements in the biography that might lend themselves to this interpretation. ${ }^{19}$ But Manetti explicitly closes off the possibility that the daimonion is a vehicle of moral knowledge. Following Apuleius, ${ }^{20}$ the Florentine distinguishes sharply between Socrates' natural wisdom, which was sufficient for moral guidance, and the guidance of the daimonion,

${ }^{17}$ It is this that no doubt accounts for Manetti's view of the daimonion as offering generalized moral counsel and guidance (like the daimonion in Xenophon's Socratic works) as opposed to the Platonic view of the daimonion who offers only 'intuitive certainty concerning the non-rectitude of a quite particular action [Socrates] was contemplating' (A. A. Long, How Does Socrates' Divine Sign Communicate with Him? in A Companion, p. 67). For Xenophon's interpretation of the daimonion see L.-A. Dorion, Xenophon's Socrates, ibid., p. 96, and Gera in Socrates from Antiquity, p. 38. Slightly later Manetti becomes evasive on the subject of the daimonion's cosmic rank: 'Hunc ergo bonum sive angelum sive daemonem sive deum (sic enim varie, ut tradit Augustinus, a plerisque appellatur) ...'.

${ }^{18}$ See Peter Lombard, Sentences 2.11.1. Manetti reasserts this doctrine, using Socrates as an example of its application to non-Christian figures, in G. MANETTI, De dignitate hominis, a cura di E. R. Leonard, Padova 1975, pp. 89-90 (§42).

${ }^{19}$ For instance the statement at $\$ 28$ that the Socratic paradoxes were thought by others to be divinely inspired, or the statement at $\$ 32$ that he was 'an earthly oracle of human wisdom' whose utterances were thought to be divine even by philosophers.

${ }^{20}$ 17.157-58; see also Xenophon's Apologia Socratis 12-13. 
who provided prophetic knowledge of the future. ${ }^{21}$ Socrates' wisdom remains natural, not supernatural, in its sources; it is the result of his virtue and intellect, not of some special grace.

It is when we come to the content of Socrates wisdom, his actual teachings, that Manetti's Socrates least resembles the Platonic and Stoic Socrateses and most resembles the skeptical and Xenophontean ones. Manetti's account of Socrates' moral teaching is likely to surprise and disappoint the modern reader, for the Florentine is completely silent about the doctrines associated with Socratic moral philosophy that modern scholars consider most important and characteristic. Manetti does not for instance mention the Socratic teachings

1) that no one does wrong willingly: that if we had true knowledge of virtue, we would always behave virtuously;

2) that all virtue is one: that striving for the virtues is a unified process, related in various ways to a single search for wisdom and rationality in one's behavior patterns, and that the virtues cannot conflict with each other;

3) that self-mastery is the foundation of virtue, and virtue is both a necessary and sufficient condition for happiness; that virtue is to the soul as health is to the body; and that this kind of virtue cannot be taught; ${ }^{22}$

4) that the unexamined life is not worth living; it is the only way to root out the errors that have damaged one's soul, errors that have their origin in false beliefs inherited from traditional religion and corrupt social values;

5) that only the wise man is truly free; a life not regulated by reason is a life of slavery to the passions and appetites;

6) that the correct method in moral philosophy is to examine the internal consistency of one's beliefs through a process of question-and-answer; that false beliefs have to be rooted out by use of the elenchus; and that exchanging long speeches - macrologia as the practice is called in the Gorgias (449b, 461a-462b) - does not lead to true knowledge.

All of these doctrines are well attested in sources demonstrably known to Manetti, so his decision to omit them must in some sense be intentional. Given what has already been said, we can guess some of the reasons. The humanists themselves, from the time of Petrarch onwards, claimed that virtue could be learned by reading classical texts, and that ancient eloquence and oratory were vital instruments for the spread of virtue throughout the ruling classes and down the social pyramid. So they would not have been sympathetic to Socrates' method, which regularly involved humiliation of an opponent. In their own dialogues they almost always imitated Ciceronian macrologia and not the Socratic

${ }^{21} \S 49$ : 'Eodem modo Socrates agebat; nam ubi consilio, propria sapientia; ubi vero praesagia, vi daemonis utebatur.'

${ }^{22}$ At $\$ 40$ Manetti does remark, without further discussion, that 'beatam vitam una virtute contineri prorsus existimabat [Socrates]'. 
dialogue as illustrated in the early works of Plato. ${ }^{23}$ Manetti surely also wanted to avoid obvious conflicts with Christian assumptions about human nature and the human need for salvation by God. The Pauline and Augustinian versions of Christianity in particular emphasized the weakness of the human intellect and the inability of human virtue to achieve on its own the standards set by God for man. Despite Manetti's claims for Socrates' nearly superhuman virtue, to explicate Socrates' teachings in detail, which emphasize the power of natural human reason to educe virtue, wisdom and happiness, would probably have invited too explicit a comparison with settled Christian dogmas.

Nevertheless, Manetti does discuss a few of Socrates' teachings and intellectual commitments. He spends the most space discussing Socrates' 'ethical turn': the story preserved in numerous sources that after his early studies with Anaxagoras and Archelaus of natural science (naturalis historia Manetti calls it), Socrates abandoned these studies and turned instead to ethics, a subject which he is deemed to have practically invented. Thus, in the much-repeated phrase, he brought philosophy down from the skies and placed it in the cities and even the homes of men. Manetti is fascinated by this story, as Petrarch, Salutati and Bruni had been before him, because it seemed to authorize the aspirations of the early humanists for their own culture. They wanted philosophy to abandon the fruitless obscurities of Aristotelian logic and natural philosophy as taught in the universities and to embrace a more civil philosophy, concerned with behavior and human affairs. That philosophy should be studied by statesmen engaged in the active life, not by contemplatives or by a specialized caste of experts. Echoing Petrarch's De ignorantia, Manetti faults Aristotle for merely describing virtue rather than making his readers desire it.

Insuper, licet Aristoteles de definiendis atque inter se distinguendis animi virtutibus probe egregieque tractaverit, nihil tamen accurate legentibus attulisse videbatur quo virtutes ardentius appeterentur, vita enixius evitarentur. Quod Socrates et Plato praecipue apud Graecos, apud nostros vero Cicero et Seneca prae ceteris fecisse laudantur, ut suasionibus suis ad incredibilem quendam virtutum amorem simul atque vitiorum detestationem et dormientes homines et aliud agentes vehementius excitarentur. $(\S 22){ }^{24}$

Socrates was superior to Aristotle for the same reason a humanistic education was superior to a scholastic one: the student acquired not merely theoretical knowledge of a discipline, but (in principle at least) a genuine love for virtue and a hatred for vice.

Manetti's explanation for why Socrates embraced the 'ethical turn' reflects these convictions. He offers three explanations (§15). The first, from Cicero (Acad. 1.4), is that Socrates was skeptical that anything certain or true could be known; this is described as

${ }^{23}$ The single exception known to the present writer is Raffaele Lippi Brandolini's De comparatione regni et reipublicae (c.1490), for which see Hankins, Humanism and the Origins of Modern Political Thought, in The Cambridge Companion to Renaissance Humanism, a cura di J. Kraye, Cambridge 1996, pp. 132-133. For Bruni's encounter with Socrates' critique of rhetoric in the Gorgias, see Hankins, Plato, I, pp. 53-58.

${ }^{24}$ The whole passage should be compared to FrANCESCO PETRARCA, Invectives, tr. ingl. di D. Marsh, Cambridge (Massachusetts) 2003, p. 314 (De ignorantia §107). 
the vetus opinio of the Academics. The second explanation, Diogenes Laertius (2.21), is that Socrates believed naturalis historia to be fruitless for bene beateque vivendum. The third, which comes from Augustine's City of God (8.3), is that Socrates believed that moral philosophy was a via purgativa and that moral purification was a necessary prerequisite before ascending to knowledge of the highest and most divine studies. Of these explanations Manetti seems to endorse both the first and the second, though he later (§19) amends the first and states that Socrates had knowledge of the subject matter of natural philosophy (physica) but regarded its conclusions as uncertain.

For Manetti this raised the whole problem of Socratic ignorance and what exactly it entailed and how it was related to his skepticism. As a humanist in the Petrarchan mold Manetti preferred that his hero not manifest any skepticism so radical that it would undermine the assumptions of humanist literary education or challenge Christian belief. He therefore links Socrates' professions of ignorance with his habit of irony (which Manetti, following Cicero, translates as dissimulatio).$^{25}$ In professing his ignorance he is merely adopting an ironic pose, akin to Christian humility, whose goal is to point the contrast with self-proclaimed experts and sophists who in reality lacked any true knowledge $(\S \S 19,29,30)$. In fact, as Manetti repeatedly points out, Socrates was being a maximus ironicus: he was positively bursting with knowledge of many arts and sciences, and indeed founded the whole science of ethics. Manetti brings the subject to a close by quoting Aristotle (Eth. Nic. 4.13, 1127b): 'It is the ironist who boasts the least, as Socrates used to do, who insisted on his total ignorance despite his vast knowledge.'

The other Socratic doctrines are equally instrumentalized to reinforce the portrait of Socrates that Manetti wishes to paint. He mentions that Aristotle was 'contradicted, mocked and ... despised by Aristotle ... for having defined virtue as knowledge' (20). But instead of a defense of Socrates' teaching, Manetti tries to refute Aristotle by reiterating the point that Socrates was himself considered wise and exemplary in his moral behavior by 'the consensus of all mankind and the divine oracle of Apollo'. The point is so irrelevant that one might suspect an authorial mishap of some kind. But it seems more likely that Manetti believed that the truth of Socrates' doctrine could be established by appeal to his authority rather than by argument. Thus the single most important Socratic doctrine is mentioned only as a hook to drag in yet another assertion of Socrates' wisdom and to hit at the scholastics' favorite authority Aristotle. A mention of Socrates' supposed teaching that there is no distinction between the honestum and the utile $(\S 17)$ is cited merely to prove Socrates' influence on the Stoics.

The only teaching of Socrates that Manetti foregrounds, and indeed labels the Socraticum decretum, is the doctrine that it is better to suffer than commit injustice (§39). Manetti mentions this to illustrate Socrates' deep understanding of the virtue of justice. The Florentine no doubt learned of this doctrine from Bruni's translation of the Gorgias, and Bruni had also highlighted the doctrine in the preface to his translation, directed to Pope John XXIII, ${ }^{26}$ and later in the preface to his translation of Aristotle's Politics, dedicated to Pope Eugene IV (1437):

${ }^{25}$ On Socratic irony in the Renaissance, see D. KNOX, Ironia: Medieval and Renaissance Ideas on Irony, Leiden 1989.

${ }^{26}$ Hankins, Plato, I, 53-58; see also II, 496-97. 
Socrates apud Platonem in eo libro, qui appellatur Gorgias [473a], ostendit deterius esse iniuriam facere quam pati; adeoque id probat, ut ad extremum dicat adamantinis rationibus esse probatum, quod facere iniuriam longe deterius est, quam iniuriam pati. In eodem libro Socrates docet: « $\mathrm{Si}$ iniuriam quis nobis fecerit, non esse vindictam a nobis faciendam» [474b-476a, 509c-511a].

Socrates, according to Plato in the book called Gorgias, shows that it is worse to inflict than to suffer an injury. And he presses the argument to the point of saying that he has proved by the severest logic that it is far worse to inflict than to suffer an injury. In the same book Socrates teaches that if someone does us an injury, we should not seek vengeance. What kind of teachings, by God, are these? Are they not divine, are they not very similar to Christian perfection? ${ }^{27}$

This is the only Socratic doctrine in the entire biography to which Manetti gives any emphasis, and the reason why is not far to seek. It is this doctrine which best makes the case for considering Socratic wisdom a useful philosophical endorsement of Christ's most difficult admonitions: to love one's enemies and to turn the other cheek rather than resist an evil person. The unique status of the doctrine in his biography also underlines for the modern historian Manetti's decisive rejection of the patristic view of Socrates and its replacement by a new, Renaissance image of Socrates: a civic humanist who is a paragon of conventional virtue, a good citizen and educator who, if not actually a Christian, is nevertheless a figure whom a Christian could admire and imitate.

James Hankins

Harvard University

${ }^{27}$ Latin text in LeONARDO BRUNI, Sulla perfetta traduzione, a cura di P. Viti, Napoli 2004, p. 278; English translation in The Humanism, p. 158. 